\title{
Determinants of Women Business Success: A Study among MSE's in East Gojjam Zone Administration
}

\author{
Getamesay Worku Mulat \\ Department of Management, Debre Markos University, PO Box 269, Debre Markos, Ethiopia
}

\begin{abstract}
The focus on women Entrepreneurship is becoming vital as it is the best way to reduce poverty in a sustainable way and promote economic growth through wealth and employment creation. The objective of the study is to identify determinants of women business success. The research design used in this study was explanatory research design. The respondents were selected from six Woredas of East Gojjam zone through cluster sampling technique. Primary data were collected from 259 respondents that were selected from women entrepreneurs working their business in MSE's. In addition, relevant data were collected from secondary sources. The Pearson chi-square test for association was employed to test the association between independent and dependent variables. Besides logistic regression model was used to determine the success factors of women business. The major findings of the study are vision to expand business, saving culture, creating market linkage, skill to adopt technology, and access to credit finance are significant and have positive influence on women entrepreneurs MSE's success.
\end{abstract}

Keywords: Success, Entrepreneur, MSE

DOI: $10.7176 / \mathrm{EJBM} / 11-10-08$

Publication date: April $30^{\text {th }} 2019$

\section{Introduction}

Entrepreneurship is increasingly recognized as an important driver of economic growth, productivity, innovation and employment, and it is widely accepted as a key aspect of economic dynamism. Transforming ideas into economic opportunities is the decisive issue of entrepreneurship (Hirsch and Schiefer, 2016). The only way to reduce poverty in a sustainable way is to promote economic growth, through wealth and employment creation. In developing countries MSEs are the major source of income, a breeding ground for entrepreneurs and a provider of employment (UNDP, 2008).

It is found that many female entrepreneurs are still facing a lot of obstacles to start the business and during development phase of their enterprises. Halkias et al. (2011) posit that Nigerian women from micro and small scale enterprises sectors were facing challenges such as low productivity, hard to get finance or capital and low labor force to enhance their businesses. Not only in Nigeria, a study conducted by Jamali (2009), found that similar constraints were faced by female entrepreneurs from other developing countries. Problems such as workfamily conflicts, difficulties to assess finance and entrepreneurial education, were found in the service sectors and retail businesses where women were involved (Itani et al., 2011).

An earlier study by Tambunan (2009) found that similar challenges were faced by the female entrepreneurs in Indonesia. Among the challenges were low level of education and lack of training opportunities, heavy household chores, legal or cultural constraints and lack of access to formal credit. Tambunan further reported that female entrepreneurs in Nepal have low self-confidence and high risk of sexual harassment. In United Arabia Emirates (UAE), most of the female entrepreneurs reported that their main constraints were low financial aids, low knowledge of industries and low management skills (Itani et al., 2011). While several of these challenges are in inherent to many countries, some of them are more severe in Africa, particularly in Ethiopia.

In Ethiopia the government gave special attention to Micro and Small Enterprise (MSE) development sector for the last decades. In 1998 the government formulated MSE development strategy and to implement the strategy the federal MSE trade works development agency was formed based on the establishment regulation number 33/1990 and later in 2004 based on the revised regulation number 104/1996 the agency was reformed and working hard to surmount its responsibility.

Correspondingly, in East Gojjam Zone Technical, Vocational and enterprise development office was formed to implement MSE's development strategy. Since its establishment the office start formal registration of MSE's and performs the responsibilities given by the agency. Even though the office provides different services to MSE's, after sometimes problems related with business failure were manifested.

It is, therefore, necessary to investigate what factors affect women business success and how to improve business success. Thus, the main aim of this paper is to identify the determinants of women entrepreneurs MSE's success in East Gojjam Zone.

\section{Statement of the Problem}

Entrepreneurship has becomes an important element for growth and development of most countries, especially 
after the financial crisis and economic downturn (Sowmya et al., 2010). Entrepreneurship is also claimed as the major driver of economy in the developed and developing countries (Ramadani et al., 2015). It is also reported that entrepreneurship curriculum area is growing rapidly in business schools around the world. This indicates that a lot of countries have emphasized and promoted entrepreneurship to support their economy. The opportunity to create profit and being their own employer has attracted many people to be entrepreneurs (Rose et al., 2006).

Even though, the importance was given to the entrepreneurial activity, Alam et al. (2011) claimed that female growth is still significantly lower than men and the percentage of women entering new ventures is still considered small.

Despite the contributions of entrepreneurs to the economic development, it is claimed that there are differences between male and female entrepreneurs, the females tend to use the human capital differently compared to their male counterparts. It is also claimed that male entrepreneurs are more likely to challenge and depart from industry norms, while female entrepreneurs are more likely to engage in routine learning process and in accordance to the norms which helps to enhance their confidence (Ekanem, 2015).

In addition, it is claimed that females view on their businesses are totally different from the way male do (Teoh and Chong, 2008). Some researchers claim that female entrepreneurs aim to achieve their intrinsic goals rather than maximizing the profit, they tend to perform less well on quantitative measures such as job creation, sales turnover and profitability. Some argue that these are due to the challenges that females have to go through in running the businesses. Thus, this study attempts to explore some of these challenges and their motivation factors.

In 2004 East Gojjam Zone Technical, Vocational and enterprise development office was formed and in the same year the office was established in 4 Town administrations and 16 woredas. All woredas and town administrations technical, vocational and enterprise development offices started registering Micro and Small enterprises since then. The enterprises create job opportunity for a number of employees. They also created a large number of employment opportunity for a number of employees. The offices perform the activities such as providing training, prepare business plan for entrepreneurs, facilitate production and selling place, facilitate access to credit finance, create market linkage, and conduct follow-up and supervision. However, the five year report of East Gojjam zone technical, vocational and enterprise development office indicates that most of women MSE's size in terms of number of employees and capital not increasing. Hence, the aim of this research is to identify the determinants of women MSE's success in Micro and small enterprises in East Gojjam zone.

\section{Objective of the Study}

The general objective of this study is to identify the determinants of women Entrepreneurs' business success in East Gojjam Zone Administration.

\section{Review of Related Literature}

\subsection{Women MSE's Business Success}

Success refers to the achievement of goals and objectives in any sector of human life. Though, in business, the concept of success generally refers to a firm's financial performance, it has been interpreted in many different ways. Some authors defined success from tangible (objective) points of view such as revenue or a firm's growth, personal wealth creation, profitability, turnover (Perren, 2000; Amrit et al 2000). Other study (Taormina and Lao, 2007) associated entrepreneurial success with continued business operations, operating for at least three years. Some other studies have interpreted the success from intangible points of view where intangible assets (e.g., goodwill of firm) are linked to key factors of success. Despite the fact that success has been widely studied topic in the field of entrepreneurship, no consensus on what is understood by the success of the firm can be found in the literature (Perez and Caninno, 2009).

Business success is about the achievement of goals and objectives of a company, which is not explicitly defined (Ngwangwama et al, 2013). It can also be characterized as a firm's ability to create acceptable outcomes and actions (Van Praag, 2003; Marom \& Lussier, 2014). There is no universal acceptable definition of business success and a majority of management studies measure business success from the perspective of firms' performance (Van Auken \& Werbel, 2006). In fact, firm performance is also complex and has multidimensional facets. Additionally, according to Islam et al, (2011), there are at least two pertinent dimensions of business success: (1) financial vs. nonfinancial, and (2) short- vs. long-term success. Based on this contend, there are various ways to measure business success that includes survival, profits, return on investment, sales growth, number of personnel employed, happiness, corporate reputation, and others (Schmidpeter \& Weidinger, 2014).

Similarly, for the context of small businesses, many early attempts at understanding firms' performance were made with reference to financial ratios and accounting measures. However, few scholars (Riquelme \& Watson, 2002) argued that there is lack of reliability with financial ratios and accounting data, as majority of small businesses have no formal reporting requirements on these financial data. Due to these reasons, it becomes 
impossible to obtain sufficient reliable information to measure the small businesses' success. Further to this thought, Wieder et al, (2006) added to the argument that financial accounting measures are not able to tap the essence of a firm's performance in other aspects as well, such as customer service, quality of products produced, innovation, and operational efficiency. Relying on financial data also limits the ability to explain future performance as they are historically oriented, hence can be misleading (Koufteros et al, 2014). In the background of recent political and social developments, there are many other non-financial factors that should be included to make the measurement of firm performance more effective (Abdallah \& Alnamri, 2015). Given these arguments, this study therefore only incorporated non-financial measures, which can be captured through managerial perceptions. The rationale for non-financial measures is that with limited information available on financial data of small businesses, it is impossible to quantify the respondents' performance using financial accounting measures.

There is growing evidence in literature that the main problem for MSE's in developing countries is not their small size but their isolation, which hinders access to markets, as well as to information, finance and institutional support (Swierczek \& Ha, 2003). A host of factors prevent them from realizing their full potential as entrepreneurs, where they could make significant contribution to society. These factors relate to the characteristics of entrepreneurs, psychological traits, finance, capitalization, marketing, technology, social network, gender, government policy issues, and management and performance of the firms. While several of these challenges are in inherent to many countries, some of them are more severe in Africa, particularly Ethiopia.

Research has shown that success is closely connected to education level, experience and age. Also, numerous studies (Chowdhury, 2011; Larsen and Lewis, 2007) have revealed the relationship of entrepreneurial success to environmental factors such as political environment, government, infrastructure, technology etc. Cooper (1985) reported three factors responsible for entrepreneurial development and success at the grass root level. These are antecedent influences (background factors such as family influence, skills and knowledge), the incubator organization (the nature of the organization where the entrepreneurs were employed prior to starting their own business) and environmental factors (e.g., infrastructure, political environment, access to capital, role of government etc).

It is argued that entrepreneurship is environmentally determined phenomenon (Prahalad, 2004). Indarti, N and Langenberg, M ( 2005) also reported external environment and demographic factors affecting MSE's business success. The environmental constraints can make or mar entrepreneurial decision making.

Demographically, age, gender, education, and work experience have been found to have impact on entrepreneurial success. Educated people are creative and innovative and they are always looking for something unique to fill a need or want (Ndubisi et al, 2003). The educated and experienced women are more interested in becoming entrepreneurs than non-educated and inexperienced women (Kavita et al, 2008).

\subsection{Factors of women MSE's Business Success}

\subsubsection{Entrepreneurial Competency}

Entrepreneurial competency refers to the small business owners' knowledge, skills and abilities (achieved via education, training, and experience), effectiveness of interpersonal relationships, network effects, and communication skills (Coleman, 2007; Collins-Dodd et al, 2004). Prior empirical works have established a relationship between entrepreneurial competency and business success (Coy et al., 2007; Karami et al., 2006; Eggers et al., 2013). It therefore becomes relevant to acknowledge that business owners, particularly in the micro and small business context, act as a gatekeeper. These business owners enable the internal resources of a firm to be optimized in order to achieve business success (Ahmad et al., 2010).

\subsubsection{Marketing Capability}

According Shafeek (2009) marketing is the one and only functional area that links the products or services of a business to its customers. He adds on to say, it is vitally important to ensure that this function is properly performed. A common weakness in the MSE's owner/managers lies in their failure to understand key marketing issues (Stokes and Wilson, 2006). They are of the belief that product or service concepts and standards often reflect only the perceptions of the owner, which may not be mirrored in the market place. He adds on to say, minor fluctuations in markets can topple a newly established small/micro firms, particularly where it is reliant on a small number of customers.

\subsubsection{Financial Resources}

There are various empirical studies verifying the importance of financial resources for successful business of small firms (Dyer et al., 2014). While financial resources are vital for an organization to ensure smooth operation, small enterprises often have comparatively limited resources and additionally face greater difficulty in accessing funding sources (Peris Bonet et al., 2011). They are also found to have less adequate budgetary control system and because they are still small businesses they lack the economies of scales (Thurik, 2007). Sufficient financial resources are also required for the firms to make continuous investment in terms of employee training and education, and to initiate any innovation process in an effort to sustain their competitive advantage (Dyer et al., 
2014). Lack of capital seems to be the primary reason for business failure and is considered to be the greatest problem facing small and micro business owners. This was supported by Shafeek (2009) where he said; from a business viewpoint without adequate financing, the business will be unable to maintain and acquire facilities, attract and retain capable staff, produce and market a product, or do any of the other things necessary to run a successful operation.

\subsubsection{Technological Usage}

The strategic importance of technological usage is well acknowledged in the literature as a factor that could enhance business success (Chatzoudes et al., 2015). Firms that utilize the latest technology tend to capture customers more than their competitors (Valacich \& Schneider, 2014). Specifically, small firms that have timely access to technical, industry knowledge, and insights into the latest technological breakthrough will be more successful. By adopting information and communication technologies, this can ease collaboration between small enterprises and their supply chain partners (Greene et al, 2015). Moreover, technologies such as the emarketplace for instance, may allow firms to expand globally and enter into new markets that before were inaccessible due to geographical barriers, with a minimum cost (White et al, 2007). This in turn would facilitate firms to gain and sustain competitive advantage. Few studies on small business performance have associated a strong link between technology resources and business success (Chatzoudes et al., 2015). Those studies reported that information technology as vital for the small business to sustain innovation, promote customer loyalty, and stimulate demand for other products offered by the small business.

\subsubsection{Business Plan}

According to Nieman and Nieuwenhuizen (2009) a business plan is a written document that carefully explains the business, its management team, its products and its goals together with strategies for reaching goals. It is a living document that forms part of the formal planning done by firms, and serves as a tool for reducing the risk of venture failure, a benchmark for a firm's internal performance as well as a tool for accessing funds (Nieman and Nieuwenhuizen 2009). Writing a business plan is strongly recommended when starting a business of your own (Bamberger, 1994; Zwart, 1998). Especially banks, venture capitalists and organizations that assist entrepreneurs need this information in order to analyse a business's potential and profitability. A mainly technical analysis of the marketing plan and financial plan determines whether the business plan offers interesting perspectives for the future. Small and micro firms by nature avoid formal planning, and as such do not have proper business plans. This in turn makes them not to be able to assess the firm's internal performance, fail to access funds such as loans, and also be exposed to the higher risk of venture failure. A business plan as a living document needs to be constantly updated in order for it to increase the business MSEs' chances of growing and surviving in the market.

\subsection{Conceptual Frame work}

The conceptual frame work is developed based on the evidence available in literature. The following figure establishes the relationship between independent variables and business success.

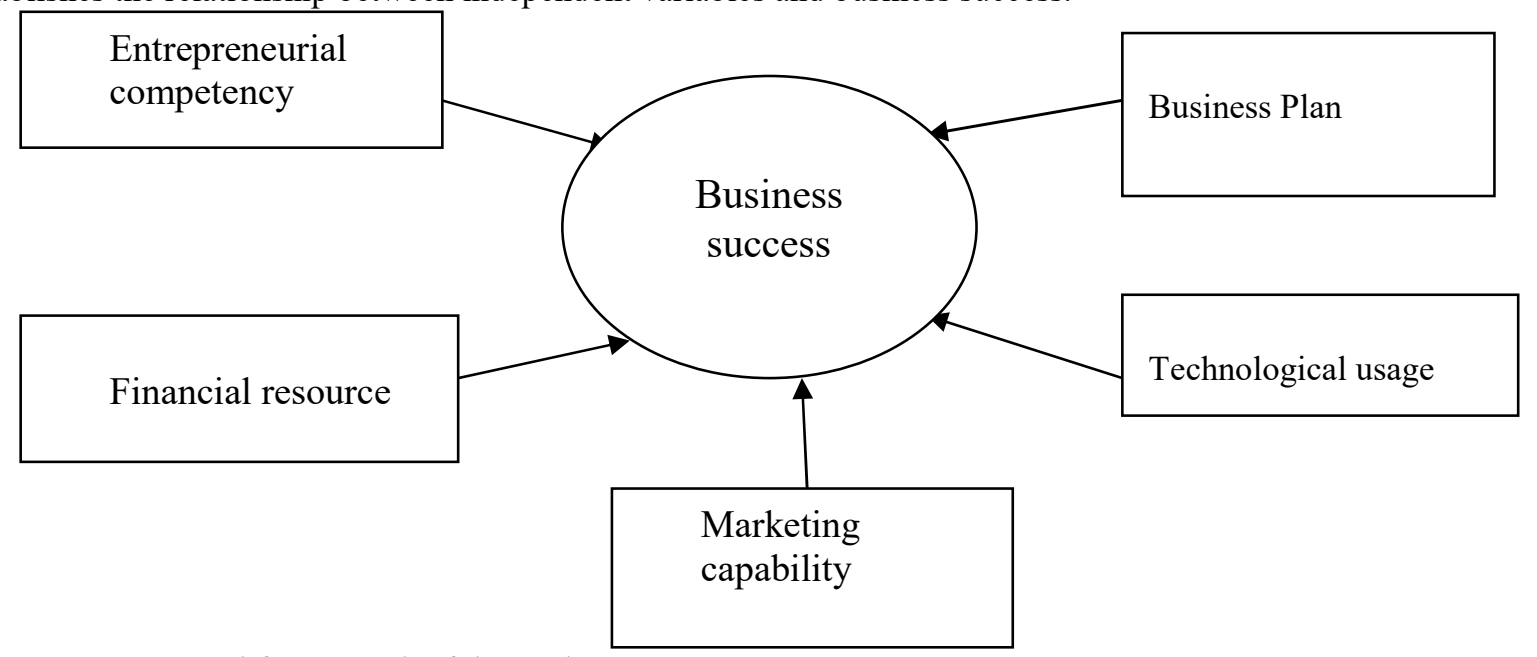

Figure 1. Conceptual frame work of the study

\section{Research Methodology}

To conduct this study, the researcher used both qualitative and quantitative types of data. In addition to this the researcher collected data from both primary and secondary sources. Quantitative approach was applied to examine, through statistical procedures, the primary data which was collected from sample respondents by means of closed-ended questionnaire. Qualitative approach was applied to analyze the data that was collected by 
means of semi- structured interview. The research design that was used in this study is explanatory research design. In this study cluster sampling was used. Data were gathered from a sample of 259 Micro and Small Enterprises. Data collections were done using questionnaires and interview. The researcher used statistical and econometric analysis methods to analyze the collected and processed data with the help of SPSS version 20 software package. The Pearson chi-square test for association employed to test the association between independent and dependent variables. Determinants factors of MSE's success were analyzed by using logistic regression.

\section{Result and Discussion}

The final results obtained in the study are presented and discussed in this part. Questionnaires were distributed to 259 respondents and all questionnaires were properly filled and returned. Moreover, additional relevant data were collected from Woredas/Town Administrations office heads and East Gojjam zone Technical, Vocational and Enterprise Development office experts through in-depth interview.

\subsection{Demographic Information}

Demographic data collected from respondents regarding education level, marital status and age are presented in Table 1 below. The purpose of this demographic information is to obtain a visualization of women entrepreneurs those own Micro and Small Enterprises.

Table 1. Demographic Information

\begin{tabular}{|l|l|r|r|}
\hline \multicolumn{1}{|c|}{ Items } & Category & Frequency & Percent \\
\hline \multirow{5}{*}{ Level of Education } & Illiterate & 14 & 5.4 \\
\cline { 2 - 4 } & Read and write & 42 & 16.3 \\
\cline { 2 - 4 } & Primary level & 38 & 14.7 \\
\cline { 2 - 4 } & Secondary level & 61 & 23.6 \\
\cline { 2 - 4 } & Certificate & 38 & 14.7 \\
\cline { 2 - 4 } & Diploma & 50 & 19.4 \\
\cline { 2 - 4 } & First degree and above & 15 & 5.8 \\
\cline { 2 - 4 } & Total & 258 & 100 \\
\hline \multirow{5}{*}{ Marital Status } & Single & 81 & 31.5 \\
\cline { 2 - 4 } & Married & 155 & 60.3 \\
\cline { 2 - 4 } & Divorced & 17 & 6.6 \\
\cline { 2 - 4 } & Widowed & 4 & 1.6 \\
\cline { 2 - 4 } & Total & 257 & 100 \\
\hline \multirow{4}{*}{ Age } & & & Mean \\
\cline { 2 - 4 } & & & 26.16 \\
\hline
\end{tabular}

For educational level of women entrepreneurs at the time of establishment, 23.6 percent of respondents are with secondary level education and 19.4 percent are with diploma. Those respondents with read and write educational level made up the third largest group at 16.3 percent, followed by respondents with primary education level and certificate at equal percent of 14.7. The smallest group of respondents with first degree and above and illiterate respondents accounts 5.8 percent and 5.4 percent respectively. This implies that the majority of women entrepreneurs have lower level of education. Hence, East Gojjam zone administration Technical, Vocational and Enterprise Development office should fill women entrepreneurs' knowledge and skill gap through well organized and continuous formal training. However, the interview result with technical, vocational and enterprise development office experts reveal that the trainings offered by the office lack considering entrepreneurs level of education. They provide training for all entrepreneurs by using similar training manual and in the same room. Hence, when the office prepare trainings they should plan based on women entrepreneurs level of education.

Intended for marital status of women entrepreneurs, 60.3 percent of respondents are married, followed by single at 31.5 percent. Divorced women entrepreneurs represented 6.6 percent and the remaining 1.6 percent of respondents are widowed. This indicates that most women entrepreneurs likely to get support from their spouse. Aimed at age of respondents at the time of establishment, the mean age of respondents is 26.16 years old. This implies that in East Gojjam zone administration the average age of women entrepreneurs is young. According to the information collected from Woredas/Town Administrations and zone technical, vocational and enterprise development office the government give special attention to women entrepreneurs particularly to youth women entrepreneurs. However, the reports from Woredas/Town Administrations show that the services offered to youth women entrepreneur are not significantly different from others groups.

\subsubsection{Characteristics of the Business}

In this part of the study the general characteristics of women entrepreneurs business such as, types of the business they are working; legal form of their business, source of startup capital and amount of initial capital are 
presented in Table 2 below.

Table 2. Characteristics of the women entrepreneurs business

\begin{tabular}{|c|c|c|c|}
\hline Items & Category & Frequency & Percent \\
\hline \multirow{4}{*}{ Forms of business } & Sole proprietorship & 141 & 54.9 \\
\hline & Partnership & 17 & 6.6 \\
\hline & Cooperatives & 99 & 38.5 \\
\hline & Total & 257 & 100.0 \\
\hline \multirow{6}{*}{ Type of the business } & Manufacturing & 48 & 18.6 \\
\hline & Service & 55 & 21.3 \\
\hline & Urban agriculture & 26 & 10.1 \\
\hline & Trade & 96 & 37.2 \\
\hline & Construction & 33 & 12.8 \\
\hline & Total & 258 & 100.0 \\
\hline \multirow{7}{*}{ Source of start-up capital } & Personal saving & 174 & 69.3 \\
\hline & Friends and Family savings & 32 & 12.7 \\
\hline & Micro finance intuitions & 25 & 10.0 \\
\hline & Traditional sources (Equb) & 9 & 3.6 \\
\hline & Other informal sources & 3 & 1.2 \\
\hline & NGO's & 8 & 3.2 \\
\hline & Total & 251 & 100.0 \\
\hline \multirow{2}{*}{ Amount of start-up capital } & & & Mean \\
\hline & & & $9,367.68$ \\
\hline
\end{tabular}

For legal form of ownership of women entrepreneurs businesses, 54.9 percent of respondents are registered their business as Sole proprietorship. While 38.5 percent of respondents working in cooperative, 6.6 percent of respondents are working in partnership. This indicates that most of women entrepreneurs established business to work alone. Moreover, the interview result with East Gojjam zone technical, vocational and enterprise development office experts shows that women entrepreneurs are not willing to work together in cooperation. Rather they would like to work alone. It is because they do not have group working culture and they do not trust each other. Yet, they are well informed about benefit of group working in getting loan, training, production and market place, using technology, and all other government supports. Hence, technical, vocational and enterprise development office should change the culture through time by providing training and consultation.

Designed for type of business in which women entrepreneurs are participating, 37.2 percent of respondents are working in trade sub sector and 21.3 percent of respondents are providing services. Women entrepreneurs working in manufacturing sub sector represented 18.6 percent, while those women working in construction and urban agriculture represented 12.8 percent and 10.1 percent respectively. This indicates that women entrepreneurs in East Gojjam zone administration are largely participating in trade and service sub sectors. Also, the interview result with East Gojjam zone technical, vocational and Enterprise development office experts shows that most women are not interested in more productive sectors like construction because of its challenges. Rather they prefer to engage in somewhat easy and less profitable sectors like trade and service. Thus, the office should encourage women entrepreneurs to participate in more profitable sectors and aware women entrepreneurs the benefits related with these sectors.

For the source of women entrepreneurs' business startup capital, 69.3 percent of respondents used their personal saving as a source of business startup capital and 12.7 percent of respondents borrowed from friends and family. While 10 percent of respondents borrow money from micro finance institutions, 3.6 percent of respondents used traditional source (equub) to start their business. The remaining 3.2 percent and 1.2 percent of respondents used from NGO's and other sources respectively. This indicates that most of women entrepreneurs start their new business by using their own personal saving. This is strongly related with the form of business they establish. Women entrepreneur will get credit finance from micro finance institutions when they work together in cooperatives. However, most of them are not interest to work together. That is why they enforced to save their own money to establish their business. This also indicates why women entrepreneurs prefer trade and service sectors because this sectors require lower startup capital than others. Hence, East Gojjam Zone technical, vocational and enterprise development office should consult women entrepreneurs about the importance of starting business through debt finance and the mechanism they can get credit from micro finance institutions.

Intended for the amount of startup capital women entrepreneurs invested to their business, the average startup capital is Birr 9,367.68. This implies that the average startup capital of women entrepreneurs in East Gojjam Administration zone is very small. The reason behind starting business by small amount of capital related with the above facts. Because of women entrepreneur prefer to work alone, they engage mostly in trade and service sectors those require less capital than others. Also they are enforced to use their personal saving as a 
source of capital. As a result the average startup capital becomes smaller. Therefore, zone level and woreda/town administration level technical, vocational and enterprise development office experts should first solve the problem of bad attitude towards cooperative works. Then problems related with choosing business sector and getting sufficient credit finance for starting business from micro finance institutions will be solved.

\subsubsection{Entrepreneurial Competency}

The statistical test result of association between entrepreneurial competency and women business success in Micro and small enterprise are presented in Table 3 below.

Table 3. Entrepreneurial competency

\begin{tabular}{|l|c|}
\hline \multicolumn{1}{|c|}{ Entrepreneurial Factors } & $P$, sign. \\
\hline Taking reasonable risk & 0.262 \\
\hline An ability to exploit opportunity & $0.030^{*}$ \\
\hline Self-confidence & 0.477 \\
\hline Innovative ability & $0.005^{*}$ \\
\hline Need for achievement & 0.361 \\
\hline Motivation to run business & $0.041^{*}$ \\
\hline Appropriate business selection skill & 0.370 \\
\hline Vision to expand business & $0.034^{*}$ \\
\hline Age & 0.973 \\
\hline Level of education & 0.090 \\
\hline
\end{tabular}

The Pearson chi square test for association results show that ability to exploit opportunity, innovative ability, motivation to run business and vision to expand business are associated significantly with business success at $5 \%$ level. Besides, the interview conduct with technical, vocational and enterprise development office experts at woreda/town administration and zone level reveal that they are providing training which will enhance entrepreneurial competency. However, the document review result show that the training provided in cooperation with poly technical and vocational college is not detail and lack the necessary contents. Hence, entrepreneurial competency affects women MSE's success. Therefore, providing entrepreneurship training and professional consultancy to enhance women entrepreneur competency will improve the likely hood of MSE's success.

\subsubsection{Financial Resource}

The Pearson chi square test for association results between financial resource and women business success in Micro and small enterprise are presented in Table 4 below.

Table 4. Financial resource

\begin{tabular}{|l|l|}
\hline \multicolumn{1}{|c|}{ Finance Resource } & $P$, sign. \\
\hline Access to credit finance & $0.000^{*}$ \\
\hline Financial management skill & $0.000^{*}$ \\
\hline Collateral securities requested by lending institutions are reasonable & $0.000^{*}$ \\
\hline Interest rate charged by lending institutions is reasonable & $0.016^{*}$ \\
\hline Adequate working capital is available & $0.001^{*}$ \\
\hline Saving culture & $0.016^{*}$ \\
\hline
\end{tabular}

The association between financial factors and business success tested. The results of Pearson chi square test for association reveal that access to credit finance, financial management skill, reasonable collateral security requested by lending institutions, reasonable interest rate charged by lending institutions, availability of adequate working capital and saving culture are associated significantly with business success at $5 \%$ level. Consequently, financial resource affects women entrepreneurs MSE's success. So, improving women entrepreneurs financial management skill, taking advantage of getting credit finance with lower interest and with a minimum collateral, and saving culture through financial management training enhance women MSE's success.

6.1.4. Marketing capability

The results of Pearson chi square test for association between marketing capability and women business success in Micro and small enterprise are presented in Table 5 below. 
Table 5. Marketing capability

\begin{tabular}{|l|c|}
\hline \multicolumn{1}{|c|}{ Marketing Capability } & $P$, sign. \\
\hline Business proximity to the customer & 0.320 \\
\hline Creating market linkage & $0.005^{*}$ \\
\hline Availability of transport facility & $0.013^{*}$ \\
\hline There is fair competition in the market & $0.025^{*}$ \\
\hline There is adequate Marketing information & 0.852 \\
\hline Customer handling skill & 0.345 \\
\hline Adequate market for product & 0.423 \\
\hline An ability of demand forecasting & 0.340 \\
\hline Regularly using local advertising to attract potential users & 0.121 \\
\hline An ability to searching new market for product & $0.013^{*}$ \\
\hline
\end{tabular}

The effects of marketing capability on women business success are tested by using Pearson chi square test for association. The test results show that creating market linkage, the availability of good transport service, the existence of fair market competition and ability to search new market for products are associated significantly with business success at 5\% level. Thus, marketing capability influence women MSE's success. As a result, by providing marketing training and professional consultancy enhancing women entrepreneur marketing capability like creating market linkage, choosing better transportation service, and ability to search new market for their product and by providing fair market competition we can enhance the success of women entrepreneur MSE's.

\subsubsection{Technology Usage}

The association between technology usage and success of women business are tested by using Pearson chi square test for association as shown in Table 6 below.

Table 6. Technology usage

\begin{tabular}{|l|l|}
\hline \multicolumn{1}{|c|}{ Technology Usage } & $P$, sign. \\
\hline Access to use the necessary technology & $0.002^{*}$ \\
\hline Cost of aquiring new technology is affordable & $0.010^{*}$ \\
\hline Skill to adopt technology & $0.046^{*}$ \\
\hline ICT tools are covenience to access market information & $0.001^{*}$ \\
\hline
\end{tabular}

The Pearson chi square test for association results show that access to use the necessary technology, affordability of new technology acquiring cost, skill to adopt technology and suitability of ICT tools to access market information are associated significantly with business success at 5\% level. For this reason, technology usage have an effect on women MSE's success. Therefore, providing necessary technology in affordable cost and enhancing women entrepreneur technology using skill improve the probability of women MSE's success.

\subsubsection{Business Plan Preparation}

The statistical test results of the association between business plan preparation and women entrepreneurs' business success are presented in Table 7 below.

Table 7. Business plan preparation

\begin{tabular}{|l|c|}
\hline \multicolumn{1}{|c|}{ Business Plan Preparation } & $P$, sign. \\
\hline Preparing business plan during establishment of business & $0.012^{*}$ \\
\hline Preparing business plan to expand your business & $0.015^{*}$ \\
\hline Preparing business plan to solve problems & $0.013^{*}$ \\
\hline
\end{tabular}

The effects of business plan preparation on women entrepreneurs' business success are tested by using Pearson chi square test for association. The test results show that preparing business plan during starting business, preparing business plan to expand business and preparing business plan to solve problem are statistically significantly associated with women business success at 5\% level. Furthermore, the interview result with East Gojjam Zone Technical, vocational and Enterprise development office authorized employees show that women entrepreneurs are not willing to prepare business plan by themselves. It is because of they do not have enough knowledge about how to write business plan. So the sector assigned experts who are responsible to prepare business plan for women entrepreneurs. Based on the information researchers got from the office entrepreneurs may consult the experts about their interest in which business sector they would like to join. Also the researchers try to check the content and depth of the business plan prepared by the office experts in consultation with the entrepreneurs. The business plan lack detail description and shallow.

\subsubsection{Logistic Regression Model}

A logistic regression was performed to identify the determinants of women MSEs Business success. The logistic regression model was statistically significant at 5\% level. The model explained $45.8 \%$ (Nagelkerke R Square) of the variance in women MSEs Business success and correctly classified $75.9 \%$ of cases. In the logistic regression analysis, the explanatory variables such as vision to expand business, saving culture, creating market linkage and skill to adopt technology are significant at 5\% level. Similarly, the explanatory variable access to credit finance 
is significant at $10 \%$ level. Therefore, these explanatory variables are associated positively with success of women MSE's Business.

\subsubsection{Reporting odds ratio}

For vision to expand business, the odds ratio indicates that women entrepreneur those have vision to expand business were 6.966 times more likely to be successful than those does not have vision to expand business. Aim at saving culture, the odds ratio indicates that women entrepreneur those have good saving culture were 5.821 times more likely to succeed than those does not have good saving culture. Intended for creating market linkage, the odds ratio indicates that women entrepreneur those created market linkage for their business by themselves were 3.006 times more likely to be successful than those does not create market linkage. Designed for skill to adopt technology, the odds ratio indicates that women entrepreneur those have necessary skill to adopt technology were 18.089 times more likely to succeed than those does not have necessary skill to adopt technology. Meant for access to credit finance, the odds ratio indicates that women entrepreneur those have access to credit finance were 3.482 times more likely to succeed than those does not have access to credit finance.

\section{Conclusions}

Most women entrepreneurs are not interested to work together in cooperation. Rather they prefer to work alone. As a result they are engaging in somewhat less challenging and less profitable sectors like trade and service. Because of this they are enforced to save their own money to establish their business by small amount of startup capital rather than using credit finance from micro finance institutions. In the logistic regression analysis, the explanatory variables such as vision to expand business, saving culture, creating market linkage and skill to adopt technology are significant. Therefore, these explanatory variables are associated positively with success of women entrepreneurs MSE's.

\section{References}

Abdallah, W.M., \& Alnamri, M. (2015). Non-financial performance measures and the BSC of multinational companies with multi-cultural environment: An empirical investigation. Cross Cultural Management, 22(4), 594-607. https://doi. org/10.1108/CCM-12-2013-0195.

Ahmad, H.N., Ramayah, T., Wilson, C., \& Kummerow, L. (2010). Is entrepreneurial competency and business success relationship contingent upon business environment? A study of Malaysian SMEs. International Journal of Entrepreneurial Behavior \& Research, 16(3), 182-203. https://doi. org/10.1108/13552551011042780.

Alam, S.S., Jani, M.F.M., Omar, N.A. (2011), An empirical study of success factors of women entrepreneurs in southern region in Malaysia. International Journal of Economics and Finance, 3(2), 166-175.

Amrit, R., MacCrimmon, K., Zietsman, C., \& Oesch, J (2000). Does money matter? Wealth attainment as the motive for initiating growth-oriented technology ventures. Journal of Business Venturing, 16(2), 119-143. http://dx.doi.org/10.1016/S0883-9026(99)00044-0.

Bamberger, I (1994), Produkt/market strategies of small and medium sized enterprises, Aveburg, Aldershot.

Chatzoudes, D., Chatzoglou, P., \& Viraimaki, E. (2015). The central role of knowledge management in business operations: Developing a new conceptual framework. Business Process Management Journal, 21(5), 11171139. https://doi. org/10.1108/BPMJ-10-2014-0099.

Chowdhury, M. (2011). Emerging women entrepreneurs in Bangladesh, The daily Starr, April.

Coleman, S. (2007). The role of human and financial capital in the profitability of growth of women-owned small firms. Journal of Small Business Management, 45(3), 303-319. https://doi.org/10.1111/j.1540627X.2007.00214.x.

Collins-Dodd, C., Gordon, I., \& Smart, C. (2004). Further evidence on the role of gender in financial performance. Journal of Small Business Management, 42(4), 395-416. https://doi.org/10.1111/j.1540627X.2004.00119.x.

Cooper, .C. (1985). The Role of Incubator Organizations in Funding of Growth Oriented Firms. Journal of Business Venturing, 1(1). http://dx.doi.org/10.1016/0883-9026(85)90008-4.

Coy, S.P., Shipley, M.F., Omer, K., \& Khan, R.N.A. (2007). Factors contributory to success: A study of Pakistan's small business owners. Journal of Developmental Entrepreneurship, 12(2), 181-198. https://doi.org/10.1142/S1084946707000617.

Dyer, W.G., Nenque, E., \& Hill, E.J. (2014). Toward a theory of family capital and entrepreneurship: Antecedents and outcomes. Journal of Small Business Management, 52(2), $266-285$. https://doi.org/10.1111/jsbm.12097.

Eggers, F., Kraus, S., Hughes, M., Laraway, S., \& Snycerski, S. (2013). Implications of customer and entrepreneurial orientations for SME growth. Management Decision, 51(3), 524-546. https://doi.org/10.1108/00251741311309643.

Ekanem, I. (2015), Entrepreneurial learning: Gender differences. International Journal of Entrepreneurial 
Behavior and Research, 21(4), 557-577.

Greene, P.G., Brush, C.G., \& Brown, T.E. (2015). Resources in small firms: An exploratory study. Journal of Small Business Strategy, 8(2), 25-40.

Halkias, D., Nwajiuba, C., Harkiolakis, N., Caracatsanis, S.M. (2011), Challenges facing women entrepreneurs in Nigeria. Management Research Review, 34(2), 221-235.

Hisrich, R.D., Bowser, K. Smarsh, L.S. (2006), Women entrepreneurs in the Ukraine. International Journal of Entrepreneurship and Small Business, 3(2), 207-221.

Indarti, N., \& Langenberg, M (2005). Factors Affecting Business Success Among SMEs: Empirical Evidences from Indonesia.(available at ww.utwente.nl/nikos/archief/research/conferences/esu/papers/indartilangenber.

Islam, M.A., Khan, M.A., Obaidullah, A.Z.M., \& Alam, M.S. (2011). Effect of entrepreneur and firm characteristics on the business success of small and medium enterprises (SMEs) in Bangladesh. International Journal of Business and Management, 6(3), 289-299.

Itani, H., Sidani, Y.M., Baalbaki, I. (2011), United Arab Emirates female entrepreneurs: Motivations and frustrations. Equality, Diversity and Inclusion An International Journal, 30(5), 409-424.

Jamali, D. (2009), Constraints and opportunities facing women entrepreneurs in developing countries: A relational perspective. Gender in Management An International Journal, 24(4), 232-251.

Karami, A., Analoui, F., \& Korak Kakabadse, N. (2006). The CEOs' characteristics and their strategy development in the UK SME sector: An empirical study. Journal of Management Development, 25(4), 316324. https://doi. org/10.1108/02621710610655800.

Kavitha, R, Anantharaman, R, \& Jayasingam, S. (2008). Motivational Factors Affecting Entrepreneurial Decision: A Comparison between Malaysian Women Entrepreneurs and Women Non Entrepreneurs, Communications of the IBIMA, Volume 8.

Koufteros, X., Verghese, A.J., \& Lucianetti, L. (2014). The effect of performance measurement systems on firm performance: A cross-sectional and a longitudinal study. Journal of Operations Management, 32(6), 313336. https://doi.org/ 10.1016/j.jom.2014.06.003.

Larsen, P and Lewis, A (2007). How award-winning SMEs manage the barriers to innovation. Creativity and Innovation Management, 16(2), 142-151 http://dx.doi.org/10.1111/j.1540-627X.2006.00185.x.

Marom, S., \& Lussier, R.N. (2014). A business success versus failure prediction model for small businesses in Israel. Business and Economic Research, 4(2), 63-81. https:// doi.org/10.5296/ber.v4i2.5997.

Ndubisi, O, Gupta, K, \& Massoud, S. (2003). Organizational Learning and Vendor Support Quality By The Usage of Application Software Packages: A Study of Asian Entrepreneurs. Journal of Systems Science and Systems Engineering 12(3), 314-331. http://dx.doi.org/10.1108/03090591011023961.

Ngwangwama, M.M., Ungerer, M., \& Morrison, J. (2013). An exploratory study of key success factors for business success of companies in the Namibian tertiary industry. International Journal of Innovations in Business, 2(6), 604-629.

Nieman, G. and Nieuwenhuizen, C. (2009) Entrepreneurship. A South African Perspective. 2nd Edition, Van Schaik, Pretoria.

Perez, E, \& Canino, R. (2009). The importance of Entrepreneur's perception of success. Review Of International Comparative Management, 10(5), 990-1010.

Peris Bonet, F., Rueda Armengot, C., \& Ángel Galindo Martín, M. (2011). Entrepreneurial success and human resources. International Journal of Manpower, 32(1), 68-80. https://doi.org/10.1108/01437721111121233.

Perren, L (2000). Factors in the growth of micro-enterprises: Exploring the implications. Journal of Small Business and Enterprise Development, 7(1) 58-68. http://dx.doi.org/10.1108/EUM0000000006805.

Prahald, K. (2004), The fortune at the Bottom of the Pyramid: Eradicating poverty through profits, Wharton School Publishing, University of Pennsylvania, Philadelphia, P.A.

Ramadani, V., Hisrich, R.D., Gerguri, S. (2015), Female entrepreneurs in transition economies: Insights from Albania, Macedonia and Kosovo. World Review and Entrepreneurship, Management and Sustainable Development, 11(4), 391-413.

Riquelme, H., \& Watson, J. (2002). Do venture capitalists' implicit theories on new business success/failure have empirical validity? International Small Business Journal, 20(4), 395-420. https://doi.org/10.1177/0266242602204002.

Rose, R.C., Kumar, N., Lim, L.Y. (2006), The dynamics of entrepreneurs success factors in influencing venture growth. Journal of Asia Entrepreneurship and Sustainability, 2(3), 1-19.

Schmidpeter, R., \& Weidinger, C. (2014). Linking business and society: An overview. In C. Weidinger (Ed.), Business success through sustainability (pp. 287-301). BerlinHeidelberg: Springer. https://doi.org/10.1007/978-3-642-38753-1_1.

Shafeek Sha (2009). Enhancing the Strategy for Developing Small Growth Potential Firms in the Eastern Cape. From <http://www.accademicjournals.org/AJBM $>$ (Retrieved 22 September 2010).

Sowmya, D.V., Majumdar, S., Gallant, M. (2010), Relevance of education for potential entrepreneurs: An 
international investigation. Journal of Small Business and Enterprise Development, 17(4), 626-640.

Stokes, D. and Wilson, N. (2006) Small Business Management and Entrepreneurship. 5th Edition, Thomson Learning, London.

Swierczek, F. W., \& Ha, T. T. (2003). Entrepreneurial orientation, uncertainty avoidance and firm performance: an analysis of Thai and Vietnamese SMEs. International Journal of Entrepreneurship and Innovation, 4(1), 46-58. http://dx.doi.org/10.5367/000000003101299393.

Tambunan, T. (2009), Women entrepreneurship in Asian developing countries: Their development and main constraints. Journal of Development and Agricultural Economics, 1(2), 027-040.

Taormina, J, \& Lao, S. K M. (2007) Measuring Chinese entrepreneurial motivation: Personality and environmental influences, International Journal of Entrepreneurial Behavior and Research, 13(4), 200-221. http://dx.doi.org/10.1108/13552550710759997.

Teoh, W.M.Y., Chong, S.C. (2008), Improving women entrepreneurs in small and medium enterprises in Malaysia: Policy recommendations. Communication of IBIMA, 2, 31-38.

Thurik, M. (2007). Policy induced constraints on small enterprise development in Asian developing countries: Small enterprise development. Journal of Small Business, 5(2), 66-77.

UNDP (2008) Innovative approaches to promoting women's economic empowerment New York: UNDP

Valacich J.S., \& Schneider, S. (2014), Enhancing information system today: Managing in the digital world (6th ed.). Boston M.A.: Pearson Education.

Van Auken, H., \& Werbel, J. (2006). Family dynamic and family business financial performance: Spousal commitment. Family Business Review, 19(1), 49-63. https://doi.org/10.1111/j.1741-6248.2006.00059.x.

Van Praag, C. M. (2003). Business survival and success of young small business owners. Small Business Economics, 21(1), 1-17. https://doi.org/10.1023/A:1024453200297.

White, A., Daniel, E., Ward, J., \& Wilson, H. (2007). The adoption of consortium B2B e-marketplace: An exploratory study. The Journal of Strategic Information Systems, 16(1),71-103. https://doi.org/10.1016/j.jsis.2007.01.004.

Wieder, B., Booth, P., Matolcsy, Z.P., \& Ossimitz, M.L. (2006). The impact of ERP systems on firm and business process performance. Journal of Enterprise Information Management, 19(1), 13-29. https://doi.org/10.1108/17410390610636850.

Zwart. P. S. (1998), "Het ondernemingsplan", in: Handboek ondernemers en adviseurs in het MKB (edited by Scherjon, D. \& Thurik, A.), Deventer, Kluwer. 